\title{
EFFECT OF SPACING AND DIFFERENT DOSES OF ORGANIC FERTILIZER TO GROWTH AND YIELD OF OKRA PLANT
}

\author{
Ilma Kurnia Pangestuti ${ }^{1}$ \\ ${ }^{1,2}$ Islamic University of Balitar; Jl. Majapahit No.04, Telp. (0342) 813145 \\ ${ }^{3}$ Jurusan Agrobisnis, FP Universitas Islam Balitar, Blitar \\ e-mail: *1 ilmakurniap@gmail.com,
}

\begin{abstract}
ABSTRAK
Penelitian ini bertujuan 1) Untuk mengetahui interaksi pupuk organik dan jarak tanam terhadap pertumbuhan dan produksi tanaman okra. 2) Untuk mengetahui dosis pupuk organic yang terbaik terhadap pertumbuhan dan produksi tanaman okra. 3) Untuk mengetahui jarak tanam yang terbaik terhadap pertumbuhan dan produksi tanaman okra. Penelitian ini dilakukan dengan menggunakan Rancangan Acak Kelompok yang disusun secara Faktorial (RAK) dengan 2 faktor, faktor pertama yaitu dosis pupuk organic $(P)$ yang terdiri dari 3 taraf yaitu $1000 \mathrm{~kg}$ ha-1(P1), $2000 \mathrm{~kg}$ ha-1 (P2), $3000 \mathrm{~kg}$ ha-1 (P3). Faktor kedua yaitu jarak tanam (J) terdiri dari 3 taraf yaitu : $50 \times 40 \mathrm{~cm}(\mathrm{~J} 1), 50 \times 50 \mathrm{~cm}$ (J2), $50 \times 60 \mathrm{~cm}(\mathrm{~J} 3)$. Variabel yang diamati meliputi tinggi tanaman, diameter batang, jumlah daun, jumlah polong total, bobot polong total dan kualitas polong. Data dianalisis menggunakan analisis ragam (ANOVA) taraf 5\% dan uji lanjut dengan Duncan's Multiple Range Test (DMRT). Hasil penelitian menunjukkan bahwa : Tidak ada interaksi yang nyata antara dosis pupuk organik dan jarak tanam terhadap pertumbuhan dan produksi tanaman okra. Perlakuan dosis pupuk organik petroganik $3000 \mathrm{~kg}$ ha-1(P3) berpengaruh nyata terhadap jumlah daun hasil yang terbaik sebesar 6,88 umur 21 HST. Perlakuan jarak tanam $50 \times 40 \mathrm{~cm}$ (J1) berpengaruh nyata terhadap tinggi tanaman, jumlah polong total dan bobot polong total. Tinggi tanaman hasil yang terbaik $60,65 \mathrm{~cm}$ dan 55,40 padaiumur 45 dan 56 HST, jumlah polong total sebesar 328,44 dan bobot polong total $3345,56 \mathrm{~g}$ pada semua pemanenan. Jarak tanam $50 \times 60 \mathrm{~cm}(\mathrm{~J} 3)$ berpengaruh nyata terhadap diameter batang hasil tetinggi $1,58 \mathrm{~cm}, 1,78 \mathrm{~cm}, 2,01 \mathrm{~cm}$ pada umur 42,49 , dan 56 HST.
\end{abstract}

\section{Kata kunci : Jarak Tanam, Pupuk Organik, Okra}

\section{INTRODUCTION}

Indonesia is a country with soil fertile, as evidenced by the large diversity of plants produced and growing well. One of them is okra or better known as arabic beans. Okra (Abelmoschus esculentus L.) is a plant originating from the region of tropical Africa. The okra plant in Indonesia planted since 1877 in West Kalimantan, planted by Chinese farmers who were liked for their daily needs (Santoso, 2006). Okra is classified as a vegetable plant, the part consumed is the fruit to be processed into various tasty and beneficial dishes for health. 
JOSAR, Vol. 1 No. 1 March, 2018; p-ISSN: 2502-8251; e-ISSN: 2503-1155

Copyrights@ Balitar Islamic University, Blitar-Indonesia

https://ejournal.unisbablitar.ac.id/index.php/josar

Nadira (2009) explain that young okra fruit contains high levels of water $85.70 \%$ protein $8.30 \%, 2.05 \%$ fat, carbohydrates $1.4 \%$ and $38.9 \%$ of calories per 100 grams. At 100 grams of okra there is also 40 kcal of energy, carotine (pro-vitamin A), and iron (Carotine) of $116 \mathrm{mg}$ (Ida wati, 2014). Okra slime in the fruit can be used as a material ser ta processing industry as a remedy for recover dysentery, stomach irritation, irritable bowel large bronchitis, gonorrhea (Lim, 2012). Okra fruit compounds can also memu lihkan mellitus diabetes patients because it can lower blood sugar levels in the body (Amin 2011).

The growing well is need for okra makes it much be producted. By the way, in some tropical countries have not yet achieved yield of okra optimum (2-3 ton / ha) and good quality, due to declining soil fertility (Abd El-Kader et al., 2010). Therefore, to meet the needs of okra do enhancing growth and production okra plants by means of fertilization and spacing.

Orgainic fertilizer which is a recommendation from the department of agriculture, namely $p$ etroganik. Petroganik Fertilizer has a specification of Organic C content of $12.5 \%, \mathrm{C} / \mathrm{N}$ ratio of $10-25 \%, \mathrm{pH} 4-8$, and moisture content 4-12 \%. PT. Petro Kimia Gresik (2008) recommends that the doses of petroganic fertilizers used are $500-2000 \mathrm{~kg} / \mathrm{ha}$. Pranata et al. (2015) mention that usage fertilizer Petroganik $2000 \mathrm{~kg} / \mathrm{ha}$ can increase the number of okra fruit $7808.87 \mathrm{~g}$ per plot. Organic fertilizers added to the soil to increase content of $\mathrm{N}, \mathrm{P}$ and $\mathrm{K}$ as well as micro element.

In addition to providing nutrients to plants, use also affects the spacing of for appropriate spacing of also can produce production okra optimally, conversely if the improper spacing will be give production and the quality of the okra low . plant spacing for plants okra ranges from 60$80 \mathrm{~cm}$ in one row with $20-30 \mathrm{~cm}$ distance between lines. Kirana, et al. (2015) states that okra plants are around $90-125 \mathrm{~cm}$ in one row and 28-62 $\mathrm{cm}$ between rows. From the results of Maurya's research, et al. (2013) 
JOSAR, Vol. 1 No. 1 March, 2018; p-ISSN: 2502-8251; e-ISSN: 2503-1155

Copyrights@ Balitar Islamic University, Blitar-Indonesia

https://ejournal.unisbablitar.ac.id/index.php/josar

Distance plant $30 \times 45 \mathrm{~cm}$ produce plant okra highest, while the results lowest on treatment of spacing of $60 \times 45 \mathrm{~cm}$.

The purpose of this study: 1) To knowing interaction of organic fertilizers and cropping distance of the growth and yield of okra. 2) To knowing doses of organic fertilizer is best on the growth and yield of okra. 3) For knowing the appropriate spacing for growth and production of okra plants.

\section{METHODOLOGY}

\section{Place and time}

Held on month study in March until June 2017 in the village of Jengglong, District Sutojayan, Blitar. Geographically Jengglong village situated at $8^{\circ} 10$ ' 0 "south latitude and $112^{\circ} 13^{\prime} 0^{\prime \prime}$ longitude east. The village topography is in the form of a plateau with an altitude of 289 masl, type soil grumosol, with temperatures around $26^{\circ}-29^{\circ} \mathrm{C}$, the average rainfall reaches $1,912 \mathrm{~mm}$ per year.

\section{Tools and materials}

The equipment used is pails, scales, scissors, meters, ruler, hand sprayers, stringy, nameplate, wooden nursery boxes measuring $0.5 \mathrm{mx} 0.5$ $\mathrm{m}$, stationery, sorong term, and camera. The materials used are Okra seeds, petroganic fertilizers, soil, manure, baby bags, clear plastic, bamboo, boat shoes.

\section{Experimental design}

The Methods used in the study is Randomized complete block design prepared with a factorial design, the first factor dose fertilizer petroganik (P) comprises 3 levels and second factors is spacing of okra ( J) consists of 3 levels:

The first factor fertilizer doses Petroganik $(P)$ which consists of three levels ie:

$$
\begin{aligned}
& \text { P1 : Dosage } 1000 \mathrm{~kg} \mathrm{ha}^{-1} \\
& \text { P2 : Dosage } 2000 \mathrm{~kg} \mathrm{ha}^{1}
\end{aligned}
$$


JOSAR, Vol. 1 No. 1 March, 2018; p-ISSN: 2502-8251; e-ISSN: 2503-1155

Copyrights@ Balitar Islamic University, Blitar-Indonesia

https://ejournal.unisbablitar.ac.id/index.php/josar

P3 : Dosage $3000 \mathrm{~kg} \mathrm{ha}^{-1}$

Whereas the second factor is Planting Okra $(\mathrm{J})$ which consists of 3 levels namely:

$\mathrm{J} 1$ : Planting Spacing $50 \times 40 \mathrm{~cm}$

J2 : Planting Spacing $50 \times 50 \mathrm{~cm}$

J3 : The Planting Spacing $50 \times 60 \mathrm{~cm}$

Thus obtained nine combined treatment and the respective each treatment was repeated three times repetition.

\section{Data Analysis}

The average data of the observation was analyzed by using the $\mathrm{F}$ test at the level of $5 \%$, when there is difference influence between treatment, then for compare between Average treatment followed by DMRT (Duncan test).

\section{Observation variable}

In this study things that need to be observed are: plant height $(\mathrm{cm})$, stem diameter $(\mathrm{cm})$, number of branches, number of pods, total weight $(\mathrm{g})$.

\section{RESEARCH DISCUSSION}

\section{Height Plant}

Based on result analysis of variance (ANOVA) at $5 \%$ level indicates that there are no significant interaction between treatment dose of organic fertilizer and plant spacing on the growth of plant height okra in all age observations $(14,21,28,42,49$, and $56 \mathrm{HST})$. The treatment of organic fertilizer ( $P$ ) did not give a significant effect on the growth of okra plants at all ages of observations. However, in the treatment of the type of spacing ( J) has a significant effect on the height of the okra plant at the age of 49 and 56 HST. (Appendix 1) After Duncan Multiple Test 5\% for know the difference between best treatment against high plants can be seen in Table 1 in under this: 
JOSAR, Vol. 1 No. 1 March, 2018; p-ISSN: 2502-8251; e-ISSN: 2503-1155

Copyrights@ Balitar Islamic University, Blitar-Indonesia

https://ejournal.unisbablitar.ac.id/index.php/josar

Table 1. Effect of Organic Fertilizer Dosage ( $P$ ) and Planting Distance ( $\mathrm{J}$ ) Plant Okra Height at Age 14, 21, 28, 35, 42, 49 and 56 HST .

\begin{tabular}{|c|c|c|c|c|c|c|c|}
\hline \multirow[b]{2}{*}{ Treatment } & \multicolumn{7}{|c|}{ Plant Height (cm) } \\
\hline & $\begin{array}{l}14 \\
\text { HST }\end{array}$ & $\begin{array}{l}21 \\
\text { HST }\end{array}$ & $\begin{array}{l}28 \\
\text { HST }\end{array}$ & $\begin{array}{l}35 \\
\text { HST }\end{array}$ & $\begin{array}{c}42 \\
\text { HST }\end{array}$ & 49 HST & 56 HST \\
\hline \multicolumn{8}{|c|}{ Petroganic Fertilizer Dosage } \\
\hline P 1 ( $1000 \mathrm{~kg} \mathrm{ha}^{-1}$ & 16.44 & 18.33 & 22.02 & 29.33 & 41.34 & & \\
\hline ) - & $\begin{array}{l}\mathrm{a} \\
17.41\end{array}$ & $\begin{array}{l}\mathrm{a} \\
19.24\end{array}$ & $\begin{array}{l}\mathrm{a} \\
22: 59\end{array}$ & $\begin{array}{l}\mathrm{a} \\
30.07\end{array}$ & $\begin{array}{c}\mathrm{a} \\
40.99\end{array}$ & $56.71 \mathrm{a}$ & $75.12 \mathrm{a}$ \\
\hline $\begin{array}{l}\text { P } 2\left(2000 \mathrm{~kg} \mathrm{ha}^{1}\right) \\
\text { P } 3\left(3000 \mathrm{~kg} \mathrm{ha}^{-1}\right.\end{array}$ & $\begin{array}{l}\mathrm{a} \\
16.17\end{array}$ & $\begin{array}{l}\mathrm{a} \\
18.22\end{array}$ & $\begin{array}{l}\text { a.m. } \\
21.93\end{array}$ & $\begin{array}{l}\mathrm{a} \\
30.19\end{array}$ & $\begin{array}{c}\mathrm{a} \\
42.05\end{array}$ & $57.62 \mathrm{a}$ & $76.92 \mathrm{a}$ \\
\hline ) & a & $\mathrm{a}$ & a & a & a & $58.66 \mathrm{a}$ & $78.14 \mathrm{a}$ \\
\hline \multicolumn{8}{|c|}{ J Planting } \\
\hline J1 ( 50x40) & a & a & a & $\begin{array}{c}\mathrm{a} \\
30.23\end{array}$ & $\begin{array}{c}\mathrm{a} \\
41.35\end{array}$ & $60.65 \mathrm{~b}$ & 78.47 \\
\hline J2 ( $50 \times 50)$ & $\begin{array}{l}16.88 \mathrm{a} \\
17.12\end{array}$ & $\begin{array}{l}18.92 a \\
18.60\end{array}$ & $\begin{array}{l}22.50 a \\
22.10\end{array}$ & $\begin{array}{c}a \\
29.38\end{array}$ & $\begin{array}{c}\mathrm{a} \\
40.29\end{array}$ & $56.94 \mathrm{a}$ & $a b$ \\
\hline J3 ( $50 \times 60)$ & a & a & $\mathrm{a}$ & a & a & $55.40 \mathrm{a}$ & $73.58 \mathrm{a}$ \\
\hline
\end{tabular}

Description : Figures followed by the same letter and row same column do not differ significant on the Duncan test $(\alpha=0.05)$.

From Table 1 above is shown that treatment spacing of giving significant effect of different on plant height. The best treatment is in treatment of $\mathrm{J} 1(50 \times 40)$. It is suspected that the shortening of the planting distance between plants will result in smaller density resulting in the large number of the population. Besides that plant height is influenced by the spacing, the spacing that is more tight will produce better plant height (Marliah et al., 2012). Spacing conference will increase competition plant to get sunlight so that plants grow high to fulfill the needs of the intensity of sunlight optimal, in accordance with the opinion of Pangli (2014), that the closer the spacing of resulting in plant height increase, are under conditions of suboptimal light intensity so that the plant experiences etiolation.

\section{Stem Diameter}

Based on the analysis of variance (ANOVA) at $5 \%$ appoint right that no there is a significant interaction between treatment doses of organic 
JOSAR, Vol. 1 No. 1 March, 2018; p-ISSN: 2502-8251; e-ISSN: 2503-1155

Copyrights@ Balitar Islamic University, Blitar-Indonesia

https://ejournal.unisbablitar.ac.id/index.php/josar

fertilizer and plant spacing to the diameter of the plant stem okra at all ages observations $(14,21,28,42,49$, and 56 HST). The treatment of the dose of organic fertilizer ( $P$ ) is not significant to the diameter of stem of okra plants at all ages of observation. However, the treatment of spacing $(\mathrm{J})$ has a significant effect on the stem diameter of the okra plant at the age of 42,49 and $56 \mathrm{HST}$ in the okra plant. (Appendix 2) After the Duncan Multiple Test $5 \%$ for know the difference between best treatment against the trunk diameter can be seen in table 2 under this:

Table 2 . Effect of Dose organic fertilizer $(P)$ and Plant Spacing $(J)$ Against Okra Stem Diameter at 14, 21, 28, 35, 42, 49 and 56 HST.

\begin{tabular}{|c|c|c|c|c|c|c|c|}
\hline \multirow[b]{2}{*}{ Treatment } & \multicolumn{7}{|c|}{ Stem Diameter (cm) } \\
\hline & $\begin{array}{l}14 \\
\text { HST }\end{array}$ & $\begin{array}{l}21 \\
\text { HST }\end{array}$ & $\begin{array}{l}28 \\
\text { HST }\end{array}$ & $\begin{array}{l}35 \\
\text { HST }\end{array}$ & $\begin{array}{c}42 \\
\text { HST }\end{array}$ & 49 HST & 56 HST \\
\hline \multicolumn{8}{|c|}{ Petroganic Fertilizer Dosage } \\
\hline P 1 ( $1000 \mathrm{~kg} \mathrm{ha}^{-1}$ & & & & & & & \\
\hline ) & $0.40 \mathrm{a}$ & $0.59 \mathrm{a}$ & $0.89 \mathrm{a}$ & $1.30 \mathrm{a}$ & $1.52 \mathrm{a}$ & $1.67 \mathrm{a}$ & $1.94 \mathrm{a}$ \\
\hline $\begin{array}{l}\text { P } 2\left(2000 \mathrm{~kg} \mathrm{ha}^{1}\right) \\
\text { P } 3\left(3000 \mathrm{~kg} \mathrm{ha}^{-1}\right.\end{array}$ & $0.41 \mathrm{a}$ & $0.60 \mathrm{a}$ & $0.92 a$ & $1.31 \mathrm{a}$ & $1.55 \mathrm{a}$ & $1.70 \mathrm{a}$ & $1.94 \mathrm{a}$ \\
\hline ) - & $0.42 \mathrm{a}$ & $0.62 \mathrm{a}$ & $\begin{array}{l}0.94 \text { a } \\
\text { Planting }\end{array}$ & $1.32 \mathrm{a}$ & $1.54 \mathrm{a}$ & $1.69 \mathrm{a}$ & $1.98 \mathrm{a}$ \\
\hline J1 ( 50x40) & $0.40 \mathrm{a}$ & $0.61 \mathrm{a}$ & $0.93 \mathrm{a}$ & $1.30 \mathrm{a}$ & $1.47 \mathrm{a}$ & $1.60 \mathrm{a}$ & $1.86 \mathrm{a}$ \\
\hline $\mathrm{J} 2(50 \times 50)$ & $0.41 \mathrm{a}$ & $0.62 \mathrm{a}$ & $0.93 a$ & $1.32 \mathrm{a}$ & $1.57 \mathrm{~b}$ & $1.68 \mathrm{ab}$ & $1.99 \mathrm{~b}$ \\
\hline $\mathrm{J} 3(50 \times 60)$ & $0.42 \mathrm{a}$ & $0.59 \mathrm{a}$ & $0.89 \mathrm{a}$ & $1.32 \mathrm{a}$ & $1.58 \mathrm{~b}$ & $1.78 \mathrm{~b}$ & $2.01 \mathrm{~b}$ \\
\hline
\end{tabular}

Description : Figures followed by the same letter in rows and columns equal that no significant difference in Duncan test $(\alpha=0.05)$.

From table 2 above treatment shown that a spacing effect significantly different to the diameter of the stem. The best is treatment a spacing J3 (50x60). This is suspected due to competition between crops happen on the spacing of the lower result of the distance and the number of population on the plot slightly low compared to spacing others. Because proper spacing arrangements are useful for regulating plant populations so that competition in plants to obtain nutrients, water and sunlight can be evenly distributed. This is in accordance with the opinion of Brar and Sigh (2016) states that use of spacing is greater able to provide more space 
JOSAR, Vol. 1 No. 1 March, 2018; p-ISSN: 2502-8251; e-ISSN: 2503-1155

Copyrights@ Balitar Islamic University, Blitar-Indonesia

https://ejournal.unisbablitar.ac.id/index.php/josar

wide for plants to grow, se to be able to increase the size of rod and the number of branches in each plant are automatically also increases the number of plant leaves

\section{Number of Leaves}

Based on analysis of variance (ANOVA) at level of $5 \%$ shows that there was no significant interaction between treatment dose of organic fertilizer and plant spacing on the number of leaves of the plant okra in all age observations $(14,21,28,42,49$, and 56 HST). The treatment of dosage organic fertilizer significantly affected the number of leaves of the okra plant at the age of 21 HST observations. However treatment of planting material ( $\mathrm{J}$ ) did not have a significant effect on the number of leaves of the okra plant at all ages of observation. (Appendix 3) After Duncan Multiple Test 5\% for determine differences in treatment between best on the number of leaves of the plant can be seen in table 3 under this:

Table 3 . Effect of Doses Organic fertilizer $(P)$ and distance Planting $(\mathrm{J})$ to Total Leaf Okra At the age of 14, 21, 28, 35, 42 and 56 HST.

\begin{tabular}{|c|c|c|c|c|c|c|c|}
\hline \multirow[b]{2}{*}{ Treatment } & \multicolumn{7}{|c|}{ Number of Leaves } \\
\hline & $\begin{array}{l}14 \\
\text { HST }\end{array}$ & $\begin{array}{l}21 \\
\text { HST }\end{array}$ & $\begin{array}{l}28 \\
\text { HST }\end{array}$ & 35 HST & $\begin{array}{c}42 \\
\text { HST }\end{array}$ & 49 HST & 56 HST \\
\hline \multicolumn{8}{|c|}{ Petroganic Fertilizer Dosage } \\
\hline P 1 ( $1000 \mathrm{~kg} \mathrm{ha}^{-1}$ & $4.62 \mathrm{a}$ & & & & 13.44 & & \\
\hline ) & b & $6.07 \mathrm{a}$ & $8.44 \mathrm{a}$ & $\begin{array}{l}10.66 \mathrm{a} \\
11.03\end{array}$ & $\begin{array}{l}a \\
13.51\end{array}$ & $15.00 \mathrm{a}$ & $17.37 \mathrm{a}$ \\
\hline $\begin{array}{l}\text { P } 2\left(2000 \mathrm{~kg} \mathrm{ha}^{1}\right) \\
\text { P } 3\left(3000 \mathrm{~kg} \mathrm{ha}^{-1}\right.\end{array}$ & $4.44 \mathrm{a}$ & $6.44 b$ & 8.70ab & $a b$ & $\begin{array}{l}\mathrm{a} \\
14.03\end{array}$ & $15.40 \mathrm{a}$ & $17.81 \mathrm{a}$ \\
\hline ) & $4.47 \mathrm{~b}$ & $6.68 b$ & $\begin{array}{l}\text { 8.96b } \\
\text { J Planting }\end{array}$ & $11.40 \mathrm{~b}$ & a & $15.66 \mathrm{a}$ & $17.96 \mathrm{a}$ \\
\hline $\mathrm{J} 1(50 \times 40)$ & $4.62 \mathrm{a}$ & $6.25 \mathrm{a}$ & $8.92 \mathrm{a}$ & $11.11 \mathrm{a}$ & $\begin{array}{l}13.66 \\
a \\
13.70\end{array}$ & $15.29 \mathrm{a}$ & $17.74 \mathrm{a}$ \\
\hline $\mathrm{J} 2(50 \times 50)$ & $4.59 a$ & $6.40 a$ & $8.51 \mathrm{a}$ & $11.22 \mathrm{a}$ & $\begin{array}{l}\mathrm{a} \\
13.62\end{array}$ & $15.40 \mathrm{a}$ & $17.74 \mathrm{a}$ \\
\hline J3 ( $50 \times 60)$ & $4.59 \mathrm{a}$ & $6.33 \mathrm{a}$ & $8.66 \mathrm{a}$ & $10.77 \mathrm{a}$ & a & $15.37 \mathrm{a}$ & $17.66 \mathrm{a}$ \\
\hline
\end{tabular}

Description : The numbers followed by the same letter on the line and the same column do not differ significant at the Duncan test $(\alpha=$ $0.05)$. 
JOSAR, Vol. 1 No. 1 March, 2018; p-ISSN: 2502-8251; e-ISSN: 2503-1155

Copyrights@ Balitar Islamic University, Blitar-Indonesia

https://ejournal.unisbablitar.ac.id/index.php/josar

From Table 3 above, demonstrated that treatment dosage organic fertilizer $(P)$ effect of different it against the number of plant leaves okra. The best treatment is $3000 \mathrm{~kg}^{\text {organic fertilizer dosage }}{ }^{-1}$ ( P3 ). This is presumably because petroganik fertilizer contains organic- $C$ levels are high and can be used to loosen and fertilize the soil, increase the shelf and water absorption, as well as ensuring macro and micro nutrients. According to Zulkifli and Herman (2012) said that organic fertilizers contain nitrogen $(N)$, phospor $(P)$, and potassium $(K)$ nutrients which are low but contain abundant micro nutrients and are needed for plant growth. dose treatment of different organic fertilizers cause results production number of leaves different and the proper dosage would be speed up leaf formation rate (Supardi, 2011). The more fertilizers applied into the soil, it can increase nutrients content in the soil, which is used to meet the different needs of nutrients for plants spurring better plant growth and yield greater number of leaves. As said by Santi (2006) organic matter has macro and micro nutrients needed by plants, so that when applied to plants it will provide good vegetative growth in plants.

\section{Number of Pods}

Based on the analysis of variance (ANOVA) at $5 \%$ level show that there is no significant interaction between dosage of organic fertilizer and distance planting on the number of pods total plant okra at all harvesting (48, 52, 56, 60, 64, 68, 72, 76, 80, and 84 HST). organic fertilizer dose treatment $(P)$ is not significant to the number of total pods of okra plant all crops. In the treatment of planting plants $(\mathrm{J})$ significant effect on the amount of total plant okra pods all harvesting (Appendix 4). After Duncan Multiple Test $5 \%$ for know the difference between best treatment against the total number of pods can be seen in Table 4 in under this: 
JOSAR, Vol. 1 No. 1 March, 2018; p-ISSN: 2502-8251; e-ISSN: 2503-1155

Copyrights@ Balitar Islamic University, Blitar-Indonesia

https://ejournal.unisbablitar.ac.id/index.php/josar

Table 4. Effect of Dose Organic Fertilizer (P) and distance Planting $(J)$ to Total Plant Okra pods.

\begin{tabular}{cc}
\hline Treatment & Total Number of Pods \\
\hline P 1 $\left(1000 \mathrm{~kg} \mathrm{ha}^{-1}\right)$ & Petroganic Fertilizer Dosage \\
P 2 $\left(2000 \mathrm{~kg} \mathrm{ha}^{1}\right)$ & $307.56 \mathrm{a}$ \\
$\mathrm{P} 3\left(3000 \mathrm{~kg} \mathrm{ha}^{-1}\right)$ & $306.67 \mathrm{a}$ \\
& Planting Distance \\
$\mathrm{J} 1(50 \times 40)$ & $328.44 \mathrm{~b}$ \\
$\mathrm{~J} 2(50 \times 50)$ & $291.22 \mathrm{a}$ \\
$\mathrm{J} 3(50 \times 60)$ & $275.89 \mathrm{a}$ \\
\hline
\end{tabular}

Description : Figures followed by letter on the same row and column the same is not different significant on the Duncan test $(\alpha=0.05)$.

From Table 4 above, shown that treatment spacing of $(\mathrm{J})$ real influence on the number of total pods plant okra. The best treatment is for the treatment of planting a $\mathrm{J} 1(50 \times 40)$. It is suspected that treatment spacing of $50 \times 40 \mathrm{~cm}(\mathrm{~J} 1)$ is spacing smaller, a right but the number of plants plot (population) more so that their products are also is greater than at treatment wider spacing. As stated Amjad et al. (2002) that spacing over small to some extent will provide the production pieces of okra per hectare more high because of the number of plants more tires, while spacing planting wider will give fruit yield per hectare okra are fewer in number so that their production is low. Setting the appropriate spacing will create conditions for the environmental factors needed by the plants available to each plant and optimize the use of available environmental factors. In addition to it spacing arranged in such a way can produce optimum production (Jumin, 2005)

\section{Total Pod Weight}

Based on the results of analysis of variance (ANOVA) at the level of $5 \%$, it showed that there was no significant interaction between the treatment of the dosage of organic fertilizer and the spacing of the total pod weight of the okra plant in all plants $(48,52,56,60,64,68,72,76$, 80 , and 84 days after planting). Treatment dose of organic fertilizer $(P)$ no significant effect on weight total plant okra pods all crops. In the treatment 
JOSAR, Vol. 1 No. 1 March, 2018; p-ISSN: 2502-8251; e-ISSN: 2503-1155

Copyrights@ Balitar Islamic University, Blitar-Indonesia

https://ejournal.unisbablitar.ac.id/index.php/josar

(J) have significant effect on the weight of the pods total plant okra all harvesting (Appendix 5) Once performed tests DMRT 5\% for know the difference between best treatment against the weight of the pods in total can be seen in the table under this :

Table 5 . Effect of Dose organic fertilizers $(\mathrm{P})$ and Plant Spacing $(\mathrm{J})$ to Weight Pod Okra plant .

\begin{tabular}{cc}
\hline Treatment & Total Pod Weight $(\mathrm{gr})$ \\
\hline & Petroganic Fertilizer Dosage \\
P 1 $\left(1000 \mathrm{~kg} \mathrm{ha}^{-1}\right)$ & $3000.89 \mathrm{a}$ \\
$\mathrm{P} 2\left(2000 \mathrm{~kg} \mathrm{ha}^{1}\right)$ & $2989.00 \mathrm{a}$ \\
P $3\left(3000 \mathrm{~kg} \mathrm{ha}^{-1}\right)$ & $3074.11 \mathrm{a}$ \\
& Planting Distance \\
J1 $(50 \times 40)$ & $3345.56 \mathrm{~b}$ \\
J2 $(50 \times 50)$ & $2888.78 \mathrm{ab}$ \\
J3 $(50 \times 60)$ & $2829.67 \mathrm{a}$ \\
\hline Description: The numbers followed by the same letter in the same row and \\
column are not significantly different from the Duncan test ( $\alpha$ \\
$=0.05)$.
\end{tabular}

From table 5 above, it is shown that the treatment of spacing $(\mathrm{J})$ has a significant temperature on the weight of the total pods of okra plants. The best treatment is the spacing of $\mathrm{J} 1$ (50) 40$)$. It is assumed that the narrow spacing between plants is different in all treatment spacing, but with increasingly spacing of plant spacing the number of plant populations increases so that the weight of pods per plot area will increase as well. Muoneke and Mbah (2007) state that low crop pod yields at high okra population densities are compensated for with a greater number of plants per plot so as to provide a greater total yield per hectare than total yield on plants with population density low one. Nafri and Salim, 1996 (in Erdhika, 2005) state that the business of cultivating plants, spacing is one of the important aspects of cultivation because both directly and indirectly affect the final yield of a plant. Hartati et.al 1996 (in Anisa, 2013) also stated that the meeting spacing provides an advantage of being able to increase the production of broad unity, besides that plants can better cover the surface of the land so that weed growth can be suppressed. 
JOSAR, Vol. 1 No. 1 March, 2018; p-ISSN: 2502-8251; e-ISSN: 2503-1155

Copyrights@ Balitar Islamic University, Blitar-Indonesia

https://ejournal.unisbablitar.ac.id/index.php/josar

\section{Conclusion}

There was no significant interaction effect between the treatment of organic fertilizer doses and the spacing of growth and yield of okra plants at all ages of observation. Different dosages of organic fertilizer did not significantly affect the growth and production of okra plants at all ages of observation.

The use of spacing has a significant effect on the highest variable of the best treatment plants at a spacing of $50 \times 40 \mathrm{~cm}$ (J1) at the age of 49 and 54 days after planting, stem diameter at treatment spacing of $50 \times 60$ $\mathrm{cm}(\mathrm{J} 3)$ at observation age 42,49 and $54 \mathrm{HST}$, total pods in the treatment of $50 \times 40 \mathrm{~cm}$ (J1) spacing and total pod weight at $50 \times 40 \mathrm{~cm}$ (J1) spacing which is not different from $50 \times 50 \mathrm{~cm}(\mathrm{~J} 2)$ spacing.

\section{Suggestion}

From research this author recommend use dose fertilizer organic petroganik still not give results optimal for growth and productivity okra plants. So the use of organic fertilizers used can be derived from an organic fertilizer in addition to petr oganik. In addition to the use of fertilizers organic as provider element nutrient inside soil well elements macro or micro, it is necessary noticed use distance planting. A wine proper planting on plant will reduce occurrence competition deliver plant from facet nutrient elements, water requirements, and intensity rays sun. So plant expected will grow and produce corresponding its potential.

For obtain growth and production Maximum okra plants need do research more go on about influence dose fertilizer organi $k$ and use planting the right distance . 
JOSAR, Vol. 1 No. 1 March, 2018; p-ISSN: 2502-8251; e-ISSN: 2503-1155

Copyrights@ Balitar Islamic University, Blitar-Indonesia

https://ejournal.unisbablitar.ac.id/index.php/josar

\section{REFENRECES}

Abd El-Kader, A. A., S. M. Shaaban, and M. S.Abd El-Fattah. 2010. Effect of Irrigation levels and organic compost on okra plant $s$ (AbelmoschusesculentusL.) grown insandy calcareous soil. Agriculture and Biology Journal of North America 1(3):255-231

Amin, I. M. 2011. Nutritional properties of Abelmoschusesculentusas remedy tomanage diabetes mellitus : A literature review. International Conference on Biomedical Enginering and Technologi. IACSIT Press, Singapore.Ardiaz 2016

Idawati. 2012. Peluang Besar Budidaya Okra.

Yogyakarta.Pustaka Baru Press

Jumin.2005. Jarak Tanam Meningkatkan Produks jagung. Penerbit Kanisius. Yogyakarta. 10-15

Kirana, R., Redi G., dan Iteu M.H. 2015. Budidaya dan Produks Benih Okra Tersedia dalam Hortikultura.Litbang.pertanin

Lim T. K. 2012. Edible Medicina And Non-Medicinal Plants : Fruits. Springer Scienceand Business Media B.V. 3 pp. 160. Samekto. R. 2006. Pupuk Kandang. PT. Citra AjiParama.Yogyakarta.

Marliah A., Hidayat T., dan Husna N. 2012. Pengaruh Varietas dan Jarak Tanan Terhadap Pertumbuhan Kedelai. J. Agrista 16(1). Antiquorum. J. Produks Tanaman. 2(3): $11-14$.

Nadira, S., B. Hatidjah, dan Nuraeni. 2009. Pertumbuhan Dan Hasil Tanaman Okra (Abelmoschusesculentus)Pada Perlakuan Pupuk Dekaformdan Defoliasi. J. Agrisains 10(1) : 10-15. ISSN : 14123657

Pangli, M. 2014. Pengaruh Jarak Tanam terhadap Pertumbuhan dan Hasil Kedelai (Glycine max L. Merrill). Jurnal AgroPet. 11(1): 1-8.

Petroganik, 2008. Proses Pembuatan Pupuk Organik. Diarsipkan di bawah:petroganik proses. 16 Juni, 1:51 pm

Pranata, R dkk. 2015. Respon produktifitas okra (AbelmoschusesculentusL.) terhadap pemberian dosis pupuk petroganik dan puupuk N. Agritop Jurnal Ilmu-ilmu Pertanian

Santoso, H.B. 2016. Organik Urban Farming - Halaman Organik minimalis. LilyPubliser, Yogyakarta 
JOSAR, Vol. 1 No. 1 March, 2018; p-ISSN: 2502-8251; e-ISSN: 2503-1155

Copyrights@ Balitar Islamic University, Blitar-Indonesia https://ejournal.unisbablitar.ac.id/index.php/josar

Santi, T. K. 2006. Pengaruh Pemberian Pupuk Kompos Terhadap Pertumbuhan Tanaman Tomat (Lycopersicum esculentum Mill). Jurnal IImiah PROGRESSIF 3(9)

Singh, P. K., V. K. Singh, D. R. Singh, and P. N.Singh. 2012. Response of Different levels of nitrogen, spacing and green fruit picking ongrowth, fruit yield, seed yield and seed quality of okra Abelmoschusesculentus (L.)Moench]. Ann. Agric. Res. New Series33(1\&2): 36-39

Supardi, A. 2011. Aplikasi pupuk cair hasilfermentasi kotoran kambing terhadap pertumbuhan tanaman sawi (Brassica juncea) sebagai pengembangan materi mata kulia fisiologi tumbuhan. (Skripsi). FKIP Universitas Negeri Surakarta. Surakar 